\title{
EMPLOYER-FUNDED \\ EDUCATION AND TRAINING \\ - WHO RECEIVES IT?
}

\author{
Michelle Barnes
}

Statistics New Zealand

Sylvia Dixon

Department of Labour

\begin{abstract}
This paper explores variations in the receipt of employer-funded education and training across the workforce, identifying which individuals and groups are most likely (or least likely) to receive further education or training with their employer's financial support. It analyses new data that were collected in Statistics New Zealand's Survey of Working Life (SoWL) 2008. Average training rates and training days are described for different groups of employees. Regression models are then used to estimate the likelihood of receiving training for people with different personal, job and employer characteristics. Thirty-one percent of employees were identified in the SoWL as having received some employer-funded education or training in the previous 12 months. Consistent with the evidence from the international literature, we find employer-funded education and training to be unequally distributed across the workforce.
\end{abstract}

\section{Introduction}

Much of the education and training that is undertaken by working adults in developed nations is funded or sponsored by employers (OECD, 1999). Further education and training has the potential to enhance the skills and consequently the employability and earnings potential of employees and to increase the productivity of firms. In an increasingly technological and globalised economy, employees may need regular training to keep up with the changing requirements of their jobs. As the workforce gradually becomes older, the role of further education and training in keeping workforce skills up to date is also likely to increase.

This paper explores variations in the receipt of employerfunded education and training across the workforce, identifying which individuals and groups are most likely (or least likely) to receive further education or training with their employer's financial support. It analyses new data that were collected in the Survey of Working Life (SoWL). The SoWL collected detailed information on people's working arrangements, work conditions and job satisfaction. It was conducted as a supplement to Statistic New Zealand's Household Labour Force Survey in the March 2008 quarter.

The SoWL identified 31 percent of employees as having received some employer-funded education or training in the preceding 12 months. This paper looks at the characteristics of employees who participated in employer-funded education or training and aims to identify which characteristics were associated with lower/higher participation. Identifying groups of employees that have particularly low rates of participation in work-based learning may be helpful in identifying unmet needs that programmes to promote skills development in workplaces could take into account.

\section{Literature Review}

The main employee characteristic identified in the literature as influencing training was the level of qualification held. Higher education has been linked to an increased likelihood that an employee will receive employer-funded training (Shields, 1998; OECD, 1999; Draca \& Green, 2004). This can be explained by educational level being an indicator of other skills and abilities that influence both learning ability and productivity at work.

Age was also commonly reported to influence training, where younger workers generally receive the most training. As older workers have a shorter working life ahead of them, they are seen to bring in smaller returns on the training investment than younger workers (Shields, 1998). The literature also suggests that gender could have an effect on the probability of receiving employer-funded education and training if employers regard women employees as likely to leave work to have children. Long 
et al. (2000) and Booth (1991) both identified lower training among women with young or dependent children.

Looking at job characteristics, employees working longer hours and permanent employees have been identified as having higher participation in training (Draca and Green, 2004; Booth, 1991; OECD, 1999). This is explained through employees who work longer hours spending more time at work and therefore yielding more benefit from their training. Permanent employees are seen as being more likely to have long-term ties to the firm, and it has been suggested by Long et al., (2000), that firms will want to invest in employees who are more likely to stay with the firm.

Evidence of union membership having a positive relationship with training was reported by Booth (1991) and Shields (1998). This positive effect is attributed to unions supporting the training demands of their workers. It is also suggested that those employed in occupations that require a higher skill level are more likely to participate in employer-funded training (Draca \& Green, 2004). This is likely to be a result of the fact that occupations requiring higher skills also require a higher level of training to maintain these skills.

Characteristics of the employer including firm size, industry and whether the firm is publically or privately owned have been identified as affecting an employee's participation in training (Booth, 1991; Shields, 1998). Participation is reported as being higher in the public sector, possibly due to public sector managers focusing more on the quality of their products and services, while the private sector is more profit focused. Employees in larger firms have been found to have higher participation in training than employees working in small firms. It is suggested that employers in large firms provide more training because their scale allows them to provide training at a lower cost and more easily release workers from their normal duties for training. Looking at industry, Shields (1998) reported that employees in public administration, education, health and social work and the utilities industry receive significantly more training than employees in manufacturing. It was also found that those employed in industries involved in research and development had a higher probability of receiving training.

The employee's willingness to undertake education or training also needs to be considered. Although this has not typically been measured in previous studies, differences in participation are likely to arise based on employees' level of motivation to participate in training, for example, in taking up training offers or initiating the work-based training themselves.

\section{Data source and definitions}

The SoWL was conducted as a supplement to Statistics New Zealand's Household Labour Force Survey (HLFS) in the March 2008 quarter. The SoWL was the first official survey in New Zealand to investigate people's work arrangements, working conditions and job satisfaction. The overall objective of the survey was to provide data that can be used to monitor changes in the employment conditions, working arrangements and job quality of employed people in New Zealand and to better understand the reasons for and implications of these employment patterns. The SoWL interviewed 14,510 employed people in New Zealand and had a response rate of 84 percent.

Employer-funded education and training refers to any employment-related training that is partly or wholly paid for by the employer. This education or training can be organised by the employer or an external training provider, conducted in-house or externally and delivered by the company's own employees or external training providers. It does not include on-the-job training at an employee's desk or normal place of work, or attendance at conferences.

In the SoWL, all employees were asked: "In the last 12 months, have you done any training courses or study that was paid for by your employer?". Employees who said "yes" were also asked how long they had spent on that study or training in the last 12 months. The time spent was recorded in categories ranging from ' 1 day or less' to '6 months or more'.

Information on employer-funded education or training was collected from all respondents who were employees at the time of the interview, but the survey did not measure how much time they had spent in employment over the 12-month reference period. The survey's measures of training participation rates and days spent in training are likely to be affected by any differences among individuals and groups in the amount of time that was spent in employment. For example, if many teenage employees were only working for part of the last year, this would have reduced their likelihood of receiving work-related training, contributing to a lower training rate for teenagers than for other age groups (holding other factors constant).

The survey collected information on any employerfunded education and training undertaken in the last 12 months within all jobs an employee held. Job characteristics such as industry and occupation were only collected for the main job held at the time of the interview, however. This means that, in some cases, there will be discrepancies between the job characteristics used in the analysis and the characteristics of the job(s) in which the education or training was actually undertaken.

\section{Analysis}

Descriptive statistics were produced on employer-funded education and training, comparing average participation rates and the distribution of days spent on training across demographic and labour force groups. Key results are reported in Table 1 (for employee characteristics) and Table 2 (for employer and job characteristics). Additional results can be found in Barnes and Dixon (2010).

Logistic regression models were then used to estimate the direct relationship between each demographic, job or 
enterprise characteristic and the probability of receiving employer-funded education and training, adjusting for other factors. The dependent variable in all regressions is whether or not the individual participated in employerfunded education and training in the past 12 months. The range of explanatory variables included in the regressions was based on findings from the literature and includes factors that are believed to influence the probability of receiving employer-funded training in economic theory (such as age, educational attainment, job tenure and hours of work) as well as factors that have been found to be correlated with differences in training probabilities in prior research, such as ethnicity and parental status.

Specifically, the explanatory variables include age, ethnicity, highest qualification, parental status, immigration status, area type, tenure, temporary employment status, usual hours worked, union membership, occupational group, main working time, business ownership of the employer, industry and size of the employer. For more details of the various models that were estimated see Barnes and Dixon (2010).

Table 3 shows the results obtained from two of our base models, which were estimated for men and women separately. The first model includes controls for type of business ownership and the second includes controls for industry, in addition to a range of other personal, job and employer characteristics. Marginal effects were calculated from the regression coefficients, and these are reported in table 3 . The marginal effects show the estimated difference in the probability of participating in employer-funded training between different levels of a particular characteristic, while controlling for the effects of the other characteristics that are included in the model. Marginal effects that are positive indicate that the group in question was more likely to have received training than the reference group. Marginal effects that are negative indicate that the group in question was less likely to have received training than the reference group. ${ }^{1}$

\section{Summary of results and discussion}

\section{Gender}

The descriptive statistics showed no gender difference in training rates: 31 percent of both male and female employees received training in the last 12 months. In addition, there was no evidence of a significant gender difference in the average likelihood of receiving training in our regression estimates. While some studies of employer-funded training in the international literature have reported a lower rate of training for women than men, others have found no significant gender difference.

\section{Age group}

The descriptive statistics on average training rates indicate that teenagers were only half as likely to receive training as prime-aged employees. Youth workers (those aged 20-24) also had a lower average training rate. However, in the regression analysis, youth employees were not significantly less likely to receive training than employees in the 'prime' age groups. The lower average training rate of teenage and youth employees is due in large part to their lower educational attainment, tendency to work in part-time jobs and over-representation in occupations and industries that have relatively low training rates.

The regression results show that the likelihood of training did not vary much over the 25-64 age range, especially for women. For men, there is evidence of some age variation, with the likelihood of training peaking in the 25-29 age group and then declining somewhat. However, there was little variation in the likelihood of training within the 40-64 age range.

\section{Ethnic group}

In the descriptive statistics, the European, Māori and European/Māori ethnic groups all had similar average participation rates at around 31 percent. The participation rate of Pacific employees was 18 percent and that of Asian employees was 25 percent.

Adjusting for the effects of other correlated factors reduces the size of these differences, but Pacific and Asian employees continue to have a lower likelihood of training than Europeans and Māori. The adjusted differences remain sizeable and are statistically significant for Pacific employees of both genders and for Asian women but not Asian men.

We are not able to fully explain the lower training of Pacific and Asian employees using the information available in the survey. It is possible that English language barriers play some role, as a high proportion of both Pacific and Asian peoples are immigrants from nonEnglish speaking countries. Unmeasured differences in employment continuity could also be a factor if employees in these ethnic groups are less likely to work on a full-year basis than employees in other ethnic groups.

\section{Educational attainment}

More highly qualified workers were more likely to receive employer-funded training than the less well qualified, and they also tended to receive more hours of training. The participation rate for employees with no qualifications was lowest at 17 percent. It was highest for employees with a post-graduate degree or a teacher's, nurse's or technician's certificate, at 49 percent.

Figure1: Proportion of employees that participated in employer-funded education or training in last 12 months by highest qualification 


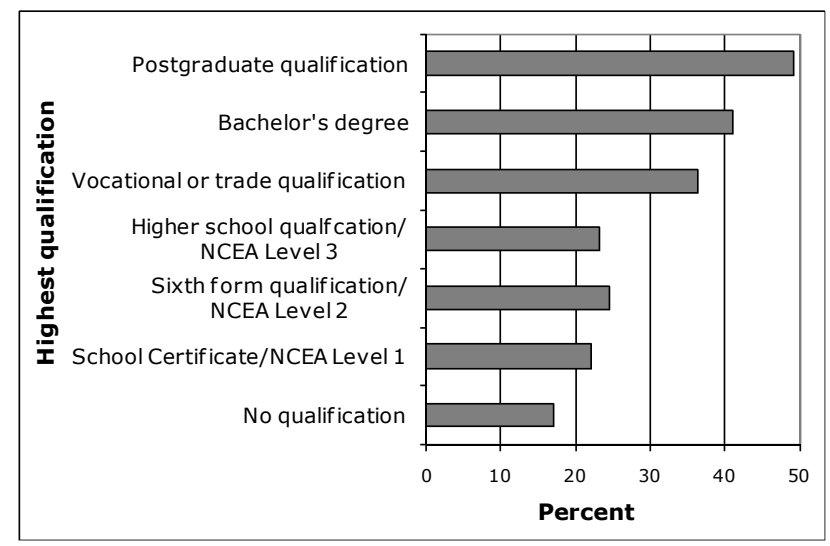

Adjusting for the effects of other personal and job characteristics reduces the size of the educational differences, reflecting the fact that workers with higher qualifications tend to be employed in jobs that have high training rates for multiple reasons. However, the variations in training by level of education remain substantial. For example, we estimate that males with a post-graduate degree were around 11-14 percentage points more likely to have undertaken some education or training during the previous year than males with lower school qualifications only.

This is consistent with past studies of the distribution of employer-funded training that have invariably found a higher rate of training among more highly educated employees. There are a number of reasons why existing educational attainment and further education tend to be complementary. For example, people who already have a high level of education may find further learning easier or may need to undertake learning activities more often during their working life to maintain or update their knowledge base.

\section{Job duration}

In the descriptive statistics on average training rates by tenure, training increased with the time spent in the job. Employees in the highest tenure group had the highest average rate of training.

After adjusting for the effects of other characteristics, however, there was no clear evidence that job tenure affects participation in training. There is little difference in the estimated training probabilities of employees in different tenure categories from 6 months upwards. Although the regression results indicate that employees who had been in their jobs for less than 6 months were significantly less likely to have trained in the last year, this could be entirely due to the fact that many of these short-tenure workers were not in paid work before starting their current job, reducing their opportunities for work-based training over the year as a whole. This means we cannot be sure that their lack of tenure with their current employer is the cause of their lower training.

\section{Temporary versus permanent employment relationship}

Average training rates calculated from the SoWL indicate permanent employees of both genders were more likely to receive training than temporary employees, although this difference was much larger among men than women, with a training rate of only 12 percent for male temporary employees compared with 23 percent for females. The participation rate for permanent employees were similar at 33 percent for males and 32 percent for females.

Much of the gap in average training rates between temporary and permanent employees can be explained by differences in age, education, hours of work, occupation and industry. After adjusting for these and other characteristics, there was no longer any significant difference between the training probabilities of women in temporary and permanent jobs. However, the regression adjustment did not fully eliminate the difference in training likelihood for men with males employed in temporary jobs 9-13 percentage points less likely to receive training that is paid for by their employer than males in permanent jobs.

There are large differences in training rates across different types of temporary job, with fixed-term employees reporting higher training than casual and seasonal employees (Dixon, 2009). Men who work in temporary jobs are more likely to be in casual or seasonal jobs than females who work in temporary jobs, and these compositional patterns help to explain the gender variations reported here.

\section{Hours of work}

The more hours an employee worked, the more likely he or she was to receive employer-funded education or training. In the descriptive statistics for New Zealand, the average participation rate was 15 percent for employees who usually worked $0-19$ hours per week, 24 percent for those working 20-29 hours per week, 33 percent for those working 40 hours a week and 39 percent for those working 50 hours per week or more.

Figure 2: Proportion of employees that participated in employer-funded education or training in last 12 months by usual hours worked per week

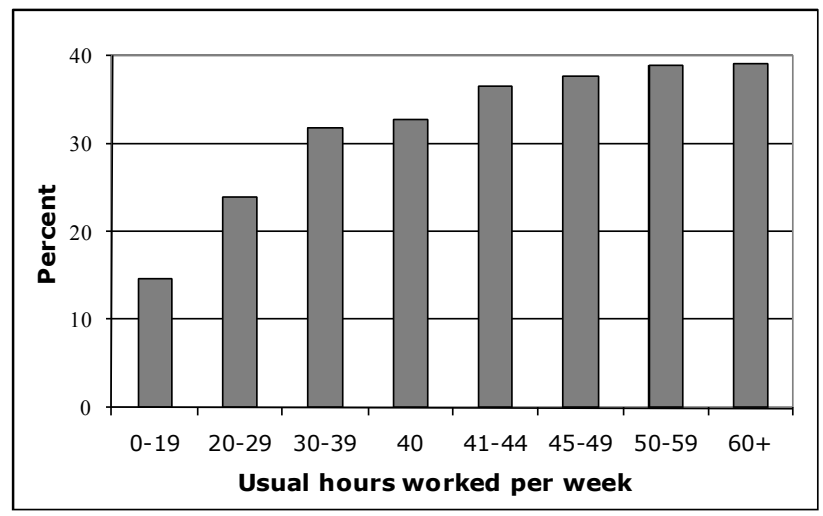

After adjusting for the effects of other characteristics, some significant differences are still evident in the likelihood of training by hours worked. The regression results indicate that people who usually worked 0-19 hours per week were about 12-14 percentage points less likely to have trained than those working 40-44 hours, while men who worked more than 45 hours a week were 
5-7 percentage points more likely to have trained than those working 40-44 hours.

Prior studies have also consistently found that part-time employees are less likely to receive training than full-time employees. This is commonly attributed to the fact that the return to the employer on any expenditure on training will be greater if an employee works more hours.

\section{Union membership}

Union membership effects have been reported in overseas studies of work-based training. In the SoWL results, union members had a much higher average training rate than employees who were not members of a union (42 percent compared with 27 percent).

One would expect any differences in average training rates between union members and non-unionised employees to be mainly due to differences in other correlated characteristics, such as occupation, industry and business ownership sector. Further analysis supports this view. Adjusting for the effects of other characteristics (including two-digit occupational group) reduces the size of the union/non-union training differential substantially. However, a small difference remains. We estimate that union membership is associated with higher training likelihood of 3-4 percentage points for men and 5-7 percentage points for women.

These results suggest that unions may raise workplace training, perhaps through collective bargaining or perhaps through the role of unions in promoting training within workplaces. An alternative explanation is that union members differ from non-unionised employees on some other dimensions that are correlated with education and training, but were not measured in the survey.

\section{Occupation}

Employees in more highly skilled occupations were more likely to study or train than employees in less skilled occupations. Average training rates varied widely by occupational group. More than half of all employees in professional occupations had undertaken employerfunded study and training in the past 12 months. The group with the lowest participation rate was the elementary occupations group, at 15 percent. Some sizeable though smaller occupational variations were found in the regression-adjusted estimates of the effects of occupation. Occupational differences in training were stronger among females than males. For both men and women, employees in professional occupations were most likely to train.

Figure 3: Proportion of employees that participated in employer-funded education or training in last 12 months by occupation

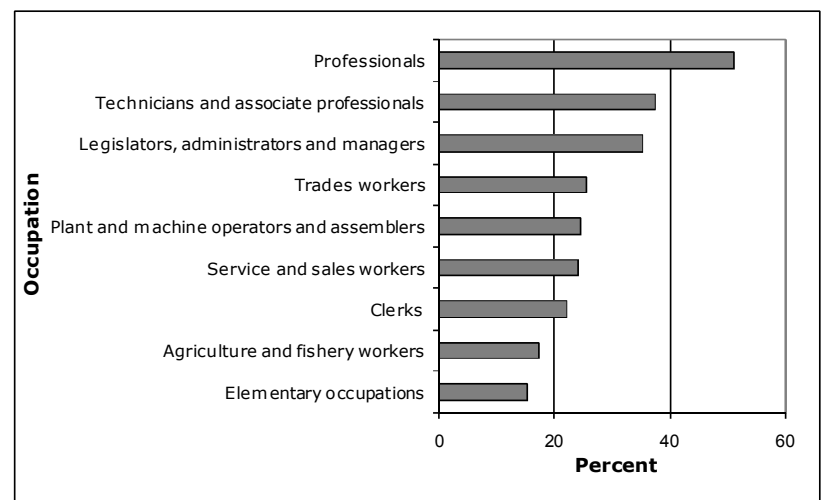

Substantial occupational variations in employer-funded training have also been identified in prior research. This reflects the fact that workers in jobs that require high levels of knowledge or skills are more likely to require life-long training to maintain or update their knowledge and skills.

\section{Business ownership type}

Employees who worked for publicly owned or non-profit organisations were more likely to receive training than those who worked for privately owned firms. The average training rates calculated in this study show that employees who worked for central government or local government organisations were almost twice as likely to have trained in the last year as those working for private sector firms. Employees who worked for non-profit organisations had the highest average rate of participation.

Figure 4: Proportion of employees that participated in employer-funded education or training in last 12 months by business ownership type

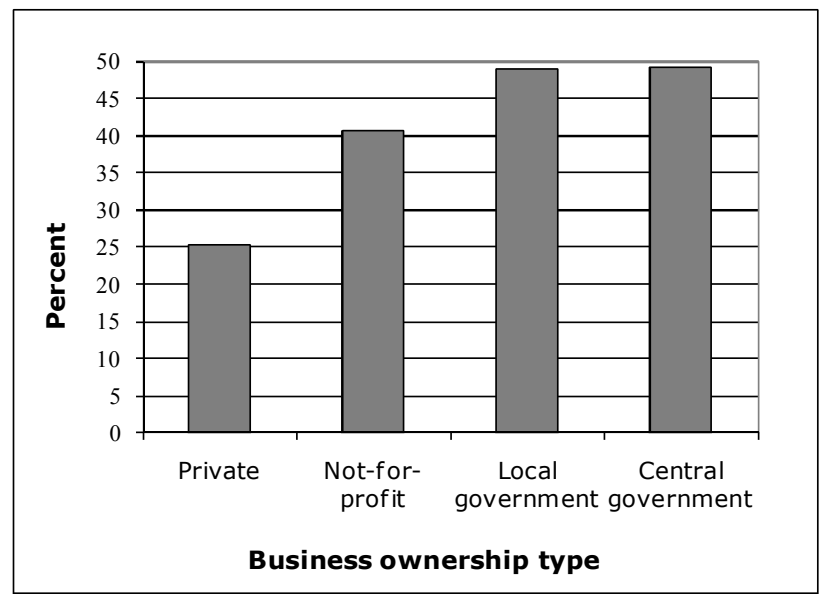

Adjusting for the effects of other correlated characteristics dramatically reduces the size of the private/public training gap but does not completely eliminate it. Our final estimates indicate that men who worked for government organisations (both central and local) were 4-6 percentage points more likely to have undertaken training than their private sector counterparts, while women who worked for government organisations were $7-8$ percentage points more likely to have undertaken training. 
The New Zealand results are in line with British and Australian evidence. The higher level of training in public and non-profit organisations could be due to the concentration of employment in particular types of service provision that have higher staff training needs, to public/private differences in training budgets and the allocation of training expenditures or to other factors that have not been included in this analysis.

\section{Size of the enterprise}

Employees who work for small organisations (those with 20 or fewer employees) are less likely to receive training than those who work for medium-sized or large organisations. The average rate of training ranged from 21 percent for employees in firms with 0-4 employees to 43 percent for employees in firms with 500 or more employees. The regression estimates indicate that, after taking other factors into account, the likelihood of having received training continues to differ substantially by firm size, although the gap between the smallest and largest firm size categories is much smaller (around 12 percentage points).

Most prior studies of the distribution of employerfinanced training have found organisational size effects, suggesting that larger firms (and larger non-profit organisations) provide a greater level of training to their employees.

\section{Industry}

There is evidence of some significant industry differences in training probabilities in this study's regression estimates, which include controls for differences in firm size and occupational structure. Employees in the accommodation, cafés and restaurants industry were least likely to have studied or trained, while employees in health and community services, personal services, and government administration had some of the highest likelihoods of studying or training.

Industry effects on training rates have been found in many prior studies, even when variations in occupational structure, firm size and other easily measured factors are taken into account. These industry effects may be due to differences in production technologies and business strategies that influence the need for or the profitability of staff training.

\section{Limitations of the research}

One of the main limitations of this study arises from the fact that the measure of education and training used in the survey was a simple question that did not distinguish between different types of training. From a policy perspective, it would be useful to be able to separately analyse patterns of participation in courses that are offered by publicly funded tertiary education institutions, industry training programmes that are delivered in workplaces with the help of government funding and courses that have no public funding. Other evidence suggests that these different types of education and training are likely to be distributed in quite different ways. Low skilled workers are more likely to participate in publicly subsidised industry training programmes, reflecting the objectives and content of these programmes, while more highly skilled workers are more likely to receive training that is solely funded by employers.

Another important limitation is that the information gathered in the survey does not shed any light on the motivations of employees and employers or the decision processes that led to the training patterns that were recorded in the survey. Both employers and employees may influence the level and allocation of employerfunded education and training. Johnson et al. (2009) provide a useful recent review of the British evidence on the intrinsic and extrinsic motivators that influence the demand for education and training.

\section{Conclusions}

Consistent with the evidence from the international literature, an employee's level of education and hours worked and the industry, ownership and size of the firm or organisation they work for have emerged as factors that are strongly correlated with participation in employer-funded education and training. Lower participation rates in employer-funded education and training were identified for male and female employees with no qualifications and for employees who worked less than 20 hours a week. Employees in the private sector were less likely to receive training than employees in the public and non-profit sectors. The likelihood of training was also found to increase with enterprise size.

This raises questions about the reasons why employers in different industries or areas of the economy approach training differently. This paper has identified the types of firms where training rates tend to be low. A broader investigation of the circumstances and skill demands of those firms would improve our understanding of the reasons for low training and, hence, the likely effectiveness of different policies to promote skill development at work.

Significant differences in training probabilities among different occupations also emerged, showing the distribution of training possibly depending on the skill requirements of the job. Union members had a higher training likelihood than non-union members, although the difference was relatively small after other factors were taken into account.

As in other countries, employer-funded education and training is unequally distributed across the workforce. Less skilled and less educated employees are less likely to receive or undertake further education and training than those with higher skills and education.

Employees who identified with the Pacific peoples ethnic group and the Asian ethnic group were less likely to receive employer-funded education and training than employees of other ethnicities. The lower participation among Pacific peoples was significant for both males and females after controlling for other demographic and job- 
related characteristics, but the lower training rate among Asian employees was only significant for females. Further investigation of the reasons why Pacific and Asian employees are less likely to receive employerfunded education and training than European and Māori employees would be useful.

\section{Notes}

1. Because the logit model is non-linear, the marginal effect of each independent variable is not constant, as in the linear regression model. Rather, it varies according to the values of all the other independent variables that are included in the model. In this paper, we adopt the conventional approach to reporting the marginal effects of each independent variable by evaluating the probabilities at the sample averages for all other independent variables.

\section{Access to Data}

Access to the data used in this report was provided by Statistics New Zealand under conditions designed to give effect to the security and confidentiality provisions of the Statistics Act 1975. The results presented in this study are the work of the author, not Statistics New Zealand.

\section{References}

Barnes, M. and Dixon, S. (2010) 'Employer-funded education and training: Who receives it?' Department of Labour research paper. http://www.dol.govt.nz/publications/research/empl oyer-funded-education-training/index.asp

Booth, A. (1991). 'Job-related formal training: Who receives it and what is it worth?'. Oxford Bulletin of Economics and Statistics, 53, 3, 281-94.
Draca, M. and Green, C. (2004). 'The incidence and intensity of employer funded training: Australian evidence on the impact of flexible work'. Scottish Journal of Political Economy, .51, 5, 609-625.

Johnson, S., Sawicki, S., Pearson, C., Lindsay, C., McQuaid, R.W. and Dutton, M. (2009). 'Employee demand for skills: A review of the evidence and policy'. UK Commission for Employment and Skills Evidence, Report 3.

Long, M., Ryan, R., Burke, G. and Hopkins, S. (2000). Enterprise-based education and training: A literature review. Ministry of Education, Wellington.

OECD. (1999). 'Training of adult workers in OECD countries: Measurement and analysis'. OECD Employment Outlook 1999, Chapter 3.

Shields, M. (1998). 'Changes in the determinants of employer-funded training for full-time employees in Britain, 1984-1994'. Oxford Bulletin of Economics and Statistics, 60, 2, 189-212. 
Table 1: Employer-funded education and training undertaken in the last 12 months, by employee characteristics

\begin{tabular}{|c|c|c|c|c|c|c|c|c|c|}
\hline \multirow[b]{3}{*}{ Employee characteristic } & \multicolumn{3}{|c|}{$\begin{array}{c}\text { Proportion of employees } \\
\text { who received employer- } \\
\text { funded study or training } \\
\text { in last } 12 \text { months }\end{array}$} & \multicolumn{6}{|c|}{$\begin{array}{c}\text { Distribution of participants by the duration of } \\
\text { training undertaken }\end{array}$} \\
\hline & Total & Males & Fem ales & $\begin{array}{l}1 \text { day } \\
\text { or less }\end{array}$ & $\begin{array}{l}2 \text { to } 5 \\
\text { days }\end{array}$ & $\begin{array}{l}6 \text { to } 10 \\
\text { days }\end{array}$ & \begin{tabular}{|c|}
11 \\
days to \\
less \\
than 1 \\
month \\
\end{tabular} & $\begin{array}{c}1 \\
\text { month } \\
\text { or } \\
\text { more }\end{array}$ & Total ${ }^{(1)}$ \\
\hline & \multicolumn{3}{|c|}{ Percent } & \multicolumn{6}{|c|}{ Row percent } \\
\hline Total all employees & 30.9 & 31.3 & 30.5 & 20.9 & 46.5 & 14.6 & 8.3 & 8.5 & 100 \\
\hline \multicolumn{10}{|l|}{ Sex } \\
\hline Male & 31.3 & 31.3 & & 21.1 & 45.3 & 15.8 & 9.9 & 7.2 & 100 \\
\hline Female & 30.5 & & 30.5 & 20.7 & 47.8 & 13.3 & 6.6 & 9.9 & 100 \\
\hline \multicolumn{10}{|l|}{ Age group ${ }^{(2)}$ (years) } \\
\hline $15-19$ & 13.6 & 14.0 & 13.2 & 36.3 & 33.6 & 12.3 & 12.0 & $\mathrm{~S}$ & 100 \\
\hline $20-24$ & 25.5 & 23.4 & 27.9 & 20.8 & 39.2 & 13.3 & 12.3 & 13.6 & 100 \\
\hline $25-29$ & 33.0 & 34.0 & 31.7 & 19.4 & 43.0 & 16.4 & 9.9 & 9.8 & 100 \\
\hline $30-34$ & 35.5 & 37.9 & 32.8 & 16.0 & 47.1 & 16.5 & 7.1 & 11.4 & 100 \\
\hline $35-39$ & 34.8 & 37.9 & 31.3 & 18.1 & 45.9 & 13.5 & 9.4 & 12.2 & 100 \\
\hline $40-44$ & 32.2 & 33.7 & 30.7 & 23.6 & 44.8 & 15.8 & 9.1 & 6.5 & 100 \\
\hline $45-49$ & 35.2 & 34.5 & 35.7 & 22.2 & 48.1 & 13.7 & 7.8 & 8.1 & 100 \\
\hline $50-54$ & 36.6 & 36.2 & 36.9 & 20.8 & 52.8 & 14.0 & 5.2 & 5.3 & 100 \\
\hline $55-59$ & 32.3 & 30.4 & 34.2 & 17.1 & 52.4 & 16.9 & 6.3 & 4.8 & 100 \\
\hline $60-64$ & 29.2 & 29.3 & 29.1 & 24.5 & 53.7 & 10.5 & 5.4 & $\mathrm{~S}$ & 100 \\
\hline $65-69$ & 18.9 & 20.0 & 17.9 & 38.7 & 41.7 & $\mathrm{~S}$ & $\mathrm{~S}$ & $\mathrm{~S}$ & 100 \\
\hline $70-74$ & 16.8 & $\mathrm{~S}$ & $\mathrm{~S}$ & $\mathrm{~S}$ & $\mathrm{~S}$ & $\mathrm{~S}$ & $\mathrm{~S}$ & $\mathrm{~S}$ & 100 \\
\hline \multicolumn{10}{|l|}{ Ethnic group } \\
\hline European only & 32.3 & 32.7 & 31.8 & 20.7 & 47.5 & 15.0 & 7.8 & 7.9 & 100 \\
\hline Māori only & 31.8 & 32.9 & 30.5 & 19.2 & 38.9 & 13.7 & 11.9 & 12.2 & 100 \\
\hline Pacific peoples only & 18.0 & 18.1 & 17.8 & 24.3 & 39.5 & 11.8 & 12.2 & 11.6 & 100 \\
\hline Asian only & 25.0 & 27.1 & 22.6 & 20.8 & 41.1 & 18.0 & 9.4 & 10.0 & 100 \\
\hline European/Māori & 30.3 & 31.0 & 29.8 & 25.8 & 44.1 & 9.7 & 9.5 & 10.5 & 100 \\
\hline Other & 29.3 & 24.6 & 34.5 & 17.6 & 55.3 & 8.4 & 7.3 & 8.2 & 100 \\
\hline \multicolumn{10}{|l|}{ Highest qualification } \\
\hline No qualification & 17.1 & 18.5 & 15.5 & 38.5 & 36.2 & 10.9 & 7.2 & 5.4 & 100 \\
\hline School Certificate/NCEA Level 1 & 22.0 & 22.4 & 21.7 & 29.2 & 42.8 & 13.9 & 7.0 & 5.6 & 100 \\
\hline Sixth form qualification/NCEA Level 2 & 24.5 & 26.3 & 23.0 & 21.1 & 50.4 & 12.6 & 11.9 & 3.6 & 100 \\
\hline Higher school qual/NCEA Level 3 & 23.1 & 27.3 & 18.9 & 21.2 & 47.0 & 18.7 & 9.0 & 3.4 & 100 \\
\hline Other school qualification nec & 17.5 & 12.8 & 20.8 & 24.7 & 54.6 & $\mathrm{~S}$ & $\mathrm{~S}$ & $\mathrm{~S}$ & 100 \\
\hline Vocational or trade qualification & 36.4 & 35.4 & 37.5 & 19.9 & 47.3 & 13.7 & 7.6 & 10.1 & 100 \\
\hline Teacher, nursing or technicians certificate & 49.5 & 51.4 & 48.9 & 16.2 & 54.4 & 13.1 & 6.9 & 7.3 & 100 \\
\hline Other certifcate or diploma & 34.2 & 34.4 & 33.9 & 20.8 & 45.5 & 13.9 & 7.8 & 10.7 & 100 \\
\hline Bachelor's degree & 41.1 & 39.8 & 42.4 & 14.9 & 51.5 & 18.0 & 5.8 & 9.3 & 100 \\
\hline Postgraduate qualification & 49.2 & 48.9 & 49.6 & 14.2 & 42.9 & 15.8 & 11.8 & 13.0 & 100 \\
\hline Other post-school qualification nec & 33.3 & 36.4 & 29.8 & 18.7 & 45.9 & 12.9 & 16.0 & 5.2 & 100 \\
\hline Total sample size & 11940 & 5630 & 6310 & & & & & & 3750 \\
\hline Estimated populaiton size (000s) & 1743.2 & 890.5 & 852.7 & & & & & & 538.9 \\
\hline
\end{tabular}

(1) Not specified is included in the totals only. (2) People aged over 74 are included in the totals only. Symbol: S = suppressed for confidentiality reasons. 
Table 2: Employer-funded education and training undertaken in the last 12 months, by job and employer characteristics

\begin{tabular}{|c|c|c|c|c|c|c|c|c|c|}
\hline \multirow{3}{*}{$\begin{array}{l}\text { Characteristic of main job or } \\
\text { employer }\end{array}$} & \multicolumn{3}{|c|}{$\begin{array}{l}\text { Proportion of employees } \\
\text { who received employer- } \\
\text { funded education or } \\
\text { training in last } 12 \text { months }\end{array}$} & \multicolumn{6}{|c|}{$\begin{array}{c}\text { Distribution of participants by the duration of } \\
\text { training undertaken }\end{array}$} \\
\hline & Total & Males & Females & $\begin{array}{l}1 \text { day } \\
\text { or less }\end{array}$ & $\begin{array}{l}2 \text { to } 5 \\
\text { days }\end{array}$ & $\begin{array}{l}6 \text { to } 10 \\
\text { days }\end{array}$ & \begin{tabular}{|c|}
11 \\
days to \\
less \\
than 1 \\
month \\
\end{tabular} & $\begin{array}{c}1 \\
\text { month } \\
\text { or } \\
\text { more }\end{array}$ & Total ${ }^{(1)}$ \\
\hline & \multicolumn{3}{|c|}{ Percent } & \multicolumn{6}{|c|}{ Row percent } \\
\hline Total all employees & 30.9 & 31.3 & 30.5 & 20.9 & 46.5 & 14.6 & 8.3 & 8.5 & 100 \\
\hline \multicolumn{10}{|l|}{$\begin{array}{l}\text { Characteristcs of main job } \\
\text { Tenure }\end{array}$} \\
\hline Less than 1 month & 12.1 & 10.2 & 13.7 & 31.3 & 39.3 & $\mathrm{~S}$ & 13.8 & $\mathrm{~S}$ & 100 \\
\hline 1 to less than 6 months & 20.0 & 20.5 & 19.5 & 21.5 & 43.5 & 15.0 & 9.4 & 7.0 & 100 \\
\hline 6 months to less than 1 year & 31.2 & 33.6 & 29.0 & 28.0 & 39.2 & 13.4 & 10.6 & 8.5 & 100 \\
\hline 1 to less than 3 years & 30.6 & 30.0 & 31.1 & 21.1 & 45.7 & 14.5 & 8.5 & 9.2 & 100 \\
\hline 3 to less than 5 years & 33.7 & 35.0 & 32.4 & 19.7 & 46.6 & 14.8 & 7.3 & 10.3 & 100 \\
\hline 5 to less than 10 years & 33.6 & 32.8 & 34.6 & 19.0 & 48.3 & 13.3 & 9.0 & 9.2 & 100 \\
\hline 10 to less than 15 years & 37.4 & 38.0 & 36.9 & 18.4 & 46.3 & 19.3 & 7.3 & 7.7 & 100 \\
\hline 15 years or more & 37.3 & 37.1 & 37.7 & 20.5 & 52.6 & 13.8 & 6.1 & 5.9 & 100 \\
\hline \multicolumn{10}{|l|}{ Employment relationship } \\
\hline Temporary employee & 18.0 & 12.1 & 22.7 & 30.5 & 48.5 & 8.7 & 6.1 & 6.2 & 100 \\
\hline Permanent employee & 32.3 & 33.1 & 31.5 & 20.3 & 46.4 & 14.9 & 8.4 & 8.7 & 100 \\
\hline \multicolumn{10}{|l|}{ Usual hours worked per week } \\
\hline $0-19$ & 14.7 & 10.3 & 16.5 & 36.2 & 47.2 & 7.0 & 4.4 & 4.8 & 100 \\
\hline $20-29$ & 24.0 & 21.2 & 24.7 & 32.8 & 43.9 & 12.0 & 5.2 & 5.5 & 100 \\
\hline $30-39$ & 31.9 & 32.3 & 31.7 & 16.6 & 50.4 & 15.4 & 6.9 & 9.3 & 100 \\
\hline 40 & 32.7 & 30.3 & 35.6 & 18.2 & 45.4 & 15.6 & 9.3 & 10.2 & 100 \\
\hline $41-44$ & 36.6 & 37.2 & 35.5 & 20.5 & 41.7 & 17.9 & 8.4 & 10.3 & 100 \\
\hline $45-49$ & 37.7 & 36.7 & 40.6 & 20.2 & 50.8 & 14.0 & 8.0 & 5.9 & 100 \\
\hline $50-59$ & 38.9 & 35.5 & 49.5 & 18.7 & 42.0 & 17.7 & 10.6 & 9.0 & 100 \\
\hline $60+$ & 39.1 & 36.8 & 51.6 & 22.4 & 51.3 & 9.7 & 9.7 & 6.2 & 100 \\
\hline \multicolumn{10}{|l|}{ Union member } \\
\hline Union member & 41.5 & 39.8 & 43.1 & 18.4 & 46.8 & 15.7 & 8.0 & 9.2 & 100 \\
\hline Not union member & 26.6 & 28.4 & 24.6 & 22.6 & 46.4 & 13.6 & 8.6 & 8.0 & 100 \\
\hline \multicolumn{10}{|l|}{ Occupation } \\
\hline Legislators, administrators and manage। & 35.2 & 35.2 & 35.1 & 13.7 & 52.8 & 17.2 & 6.9 & 8.2 & 100 \\
\hline Professionals & 51.0 & 47.6 & 53.5 & 12.1 & 50.1 & 18.0 & 9.1 & 8.8 & 100 \\
\hline Technicians and associate professionals & 37.4 & 37.4 & 37.4 & 21.8 & 42.6 & 16.2 & 7.7 & 10.5 & 100 \\
\hline Clerks & 22.1 & 29.8 & 20.0 & 28.0 & 48.2 & 9.8 & 6.4 & 7.3 & 100 \\
\hline Service and sales workers & 24.0 & 27.0 & 22.3 & 26.7 & 40.5 & 10.5 & 9.0 & 12.3 & 100 \\
\hline Agriculture and fishery workers & 17.2 & 18.6 & 14.0 & 36.5 & 37.2 & 10.0 & 12.5 & $\mathrm{~S}$ & 100 \\
\hline Trades workers & 25.6 & 26.4 & $\mathrm{~S}$ & 24.6 & 42.8 & 10.7 & 13.0 & 7.4 & 100 \\
\hline Plant and machine operators and asser & 24.5 & 26.5 & 14.9 & 36.1 & 42.4 & 11.4 & 5.7 & 3.8 & 100 \\
\hline Elementary occupations & 15.4 & 18.5 & 11.0 & 32.1 & 44.3 & 16.0 & $\mathrm{~S}$ & $\mathrm{~S}$ & 100 \\
\hline
\end{tabular}

Continued on next page. 
Table 2: Employer-funded education and training undertaken in the last 12 months, by job and employer characteristics (continued)

\begin{tabular}{|c|c|c|c|c|c|c|c|c|c|}
\hline \multirow{3}{*}{$\begin{array}{l}\text { Characteristic of main job or } \\
\text { employer }\end{array}$} & \multicolumn{3}{|c|}{$\begin{array}{l}\text { Proportion of employees } \\
\text { who received employer- } \\
\text { funded education or } \\
\text { training in last } 12 \text { months }\end{array}$} & \multicolumn{6}{|c|}{$\begin{array}{c}\text { Distribution of participants by the duration of } \\
\text { training undertaken }\end{array}$} \\
\hline & Total & Males & Females & $\begin{array}{l}1 \text { day } \\
\text { or less }\end{array}$ & $\begin{array}{l}2 \text { to } 5 \\
\text { days }\end{array}$ & $\begin{array}{l}6 \text { to } 10 \\
\text { days }\end{array}$ & \begin{tabular}{|c|}
11 \\
days to \\
less \\
than 1 \\
month \\
\end{tabular} & $\begin{array}{c}1 \\
\text { month } \\
\text { or } \\
\text { more }\end{array}$ & Total $I^{(1)}$ \\
\hline & \multicolumn{3}{|c|}{ Percent } & \multicolumn{6}{|c|}{ Row percent } \\
\hline
\end{tabular}

\section{Characteristcs of employer}

Business ownership

Private

Central government

Local government

Not-for-profit

Not classified

\section{Size of enterprise}

0 to 4 employees

5 to 9 employees

10 to 19 employees

20 to 49 employees

50 to 99 employees

100 to 499 employees

500 or more employees

Not classified

\section{Industry}

Agriculture, forestry \& fishing

Mining

Manufacturing

Electricity, gas \& water supply

Construction

Wholesale trade

Retail trade

Accommodation, cafes \& restaurants

Transport \& storage

Communication services

Finance \& insurance

Property \& business services

Government administration \& defence

Education

Health \& community services

Cultural \& recreational services

Personal \& other services

Total sample size

Estimated populaiton size (000s)

$\begin{array}{rrrrrrrrr}25.4 & 27.7 & 22.6 & 25.0 & 46.4 & 13.4 & 7.3 & 6.8 & 100 \\ 49.3 & 49.6 & 49.1 & 15.4 & 45.6 & 16.5 & 10.4 & 10.2 & 100 \\ 48.9 & 53.6 & 42.6 & 14.3 & 59.5 & 12.9 & 6.0 & 6.8 & 100 \\ 40.8 & 39.1 & 41.7 & 16.1 & 41.2 & 18.3 & 8.5 & 14.4 & 100 \\ 26.2 & 27.1 & 27.0 & 18.6 & 49.1 & 13.2 & 8.9 & 8.9 & 100\end{array}$

$\begin{array}{lllllllrl}20.9 & 22.1 & 21.5 & 20.9 & 46.3 & 12.8 & 7.5 & 11.2 & 100 \\ 23.3 & 24.2 & 23.8 & 18.3 & 46.5 & 15.2 & 9.8 & 9.5 & 100 \\ 26.9 & 29.1 & 27.7 & 24.0 & 47.1 & 15.1 & 8.0 & 5.5 & 100 \\ 33.2 & 32.8 & 32.0 & 24.8 & 48.1 & 13.5 & 6.5 & 5.7 & 100 \\ 33.9 & 33.1 & 35.0 & 20.5 & 48.0 & 12.9 & 6.4 & 10.2 & 100 \\ 35.2 & 39.3 & 30.7 & 22.1 & 48.5 & 12.5 & 7.8 & 7.7 & 100 \\ 42.7 & 42.1 & 42.8 & 19.1 & 40.8 & 18.6 & 10.3 & 10.2 & 100 \\ 26.0 & 25.4 & 26.7 & 19.3 & 49.1 & 12.9 & 8.7 & 8.6 & 100\end{array}$

\begin{tabular}{|c|c|c|c|c|c|c|c|c|}
\hline 17.5 & 19.7 & 13.1 & 30.8 & 43.7 & 11.1 & 10.4 & $\mathrm{~S}$ & 100 \\
\hline 47.6 & 50.9 & $\mathrm{~S}$ & $\mathrm{~S}$ & 62.8 & $\mathrm{~S}$ & $S$ & $\mathrm{~S}$ & 100 \\
\hline 23.5 & 24.8 & 20.3 & 29.4 & 43.1 & 12.6 & 7.7 & 6.3 & 100 \\
\hline 52.7 & 57.0 & $\mathrm{~S}$ & $\mathrm{~S}$ & 63.1 & $\mathrm{~S}$ & $S$ & $\mathrm{~S}$ & 100 \\
\hline 25.8 & 27.3 & 14.2 & 29.3 & 45.8 & 8.9 & 8.1 & 5.9 & 100 \\
\hline 25.9 & 28.5 & 20.7 & 27.7 & 54.1 & 12.9 & $S$ & $\mathrm{~S}$ & 100 \\
\hline 19.7 & 24.6 & 15.6 & 29.5 & 44.3 & 13.4 & 6.7 & 6.0 & 100 \\
\hline 11.5 & 8.7 & 13.0 & 37.2 & 43.7 & $\mathrm{~S}$ & $\mathrm{~S}$ & $\mathrm{~S}$ & 100 \\
\hline 31.9 & 29.7 & 37.0 & 28.6 & 46.1 & 10.2 & 4.8 & 10.1 & 100 \\
\hline 25.9 & 33.1 & 14.2 & 24.0 & 33.7 & 19.1 & 20.6 & $\mathrm{~S}$ & 100 \\
\hline 35.3 & 41.7 & 31.1 & 6.5 & 44.2 & 25.9 & 8.3 & 12.2 & 100 \\
\hline 31.9 & 37.2 & 26.8 & 17.7 & 48.4 & 16.4 & 7.1 & 9.9 & 100 \\
\hline 51.1 & 51.5 & 50.9 & 14.3 & 51.4 & 15.9 & 11.3 & 5.9 & 100 \\
\hline 45.8 & 46.5 & 45.5 & 13.9 & 50.7 & 16.2 & 8.7 & 8.7 & 100 \\
\hline 47.4 & 55.3 & 45.7 & 17.1 & 44.0 & 16.1 & 7.8 & 12.0 & 100 \\
\hline 27.0 & 26.0 & 28.3 & 27.0 & 50.8 & 11.3 & $\mathrm{~S}$ & $\mathrm{~S}$ & 100 \\
\hline 40.7 & 55.2 & 29.6 & 16.8 & 38.3 & 12.7 & 16.7 & 15.4 & 100 \\
\hline 10 & 5630 & 6310 & & & & & & 3750 \\
\hline 43.2 & 890.5 & 852.7 & & & & & & 538.9 \\
\hline
\end{tabular}

(1) Not specified is included in the totals only. (2) People aged over 74 are included in the totals only. Symbol: $\mathbf{S}=$ suppressed for confidentiality reasons. 
Table 3: Marginal effect estimates from regression models of the probability of receiving education or training

\begin{tabular}{|c|c|c|c|c|c|}
\hline & \multicolumn{5}{|c|}{ Regression model } \\
\hline & $\begin{array}{c}\text { Business } \\
\text { sector } \\
\text { controls }\end{array}$ & $\begin{array}{l}\text { Industry } \\
\text { controls }\end{array}$ & $\begin{array}{c}\text { Business } \\
\text { sector } \\
\text { controls }\end{array}$ & $\begin{array}{l}\text { Industry } \\
\text { controls }\end{array}$ & \\
\hline & \multicolumn{2}{|c|}{ Males } & \multicolumn{3}{|c|}{ Females } \\
\hline & \multicolumn{5}{|c|}{ Marginal effects } \\
\hline \multicolumn{6}{|l|}{ Personal characteristics } \\
\hline $15-19$ years old & 0.037 & 0.050 & -0.030 & 0.001 & \\
\hline $20-24$ years old & 0.025 & 0.035 & 0.002 & 0.013 & \\
\hline $25-29$ years old & $0.074 * *$ & $0.080 * *$ & -0.009 & -0.009 & \\
\hline $30-34$ years old & 0.063 & 0.067 & -0.003 & -0.007 & \\
\hline $35-39$ years old & 0.043 & 0.046 & -0.024 & -0.025 & \\
\hline $40-44$ years old & 0.000 & 0.000 & 0.000 & 0.000 & \\
\hline $45-49$ years old & 0.009 & 0.008 & 0.015 & 0.016 & \\
\hline $50-54$ years old & 0.031 & 0.041 & 0.016 & 0.010 & \\
\hline $55-59$ years old & -0.012 & -0.010 & 0.005 & -0.002 & \\
\hline $60-64$ years old & -0.010 & -0.010 & -0.014 & -0.023 & \\
\hline $65-69$ years old & -0.044 & -0.040 & -0.081 & -0.079 & \\
\hline European only & 0.000 & 0.000 & 0.000 & 0.000 & \\
\hline Māori only & 0.020 & 0.016 & -0.020 & -0.011 & \\
\hline European / Māori & -0.011 & -0.001 & -0.019 & -0.017 & \\
\hline Pacific peoples only & $-0.110 * *$ & $-0.109 * *$ & $-0.090 * *$ & $-0.084 *$ & $* *$ \\
\hline Asian only & -0.035 & -0.027 & $-0.085 * *$ & $-0.078 \times$ & $* *$ \\
\hline Other ethnicity & -0.034 & -0.027 & -0.004 & 0.007 & \\
\hline Post-graduate degree & $0.076 * *$ & 0.053 & -0.001 & 0.000 & \\
\hline Degree & 0.018 & 0.012 & -0.016 & -0.017 & \\
\hline Teachers/nurses/technicians cetificate or diploma & $0.108 * *$ & $0.105 * *$ & 0.024 & 0.010 & \\
\hline Other certifcate or diploma & 0.000 & 0.000 & 0.000 & 0.000 & \\
\hline Upper secondary school qualification & -0.035 & -0.028 & $-0.070 * *$ & $-0.067 *$ & $* *$ \\
\hline School certificate or NCEA level 1 & $-0.061 * *$ & $-0.058 * *$ & $-0.078 * *$ & $-0.073 *$ & ** \\
\hline No qualification & $-0.116 * *$ & $-0.111 * *$ & $-0.133 * *$ & $-0.126 *$ & $* *$ \\
\hline Not parent of dependent child/ren & 0.000 & 0.000 & 0.000 & 0.000 & \\
\hline Parent of dependent children & $0.051 * *$ & $0.052 * *$ & 0.018 & 0.019 & \\
\hline Born in New Zealand & 0.000 & 0.000 & 0.000 & 0.000 & \\
\hline Born overseas, in NZ for less than 5 years & -0.085 & -0.087 & 0.079 & 0.098 & \\
\hline Born overseas, in NZ for $5-10$ years & -0.104 & -0.092 & 0.151 & 0.171 & \\
\hline Born overseas, in NZ for more than 10 years & -0.076 & -0.075 & 0.027 & 0.045 & \\
\hline Main urban area & 0.000 & 0.000 & 0.000 & 0.000 & \\
\hline Minor urban area & $0.069 * *$ & $0.075 * *$ & 0.010 & 0.014 & \\
\hline Rural area & 0.029 & 0.033 & 0.046 & $0.052 *$ & $* *$ \\
\hline \multicolumn{6}{|l|}{ Job characteristics } \\
\hline Less than 1 month & $-0.171 * *$ & $-0.164 * *$ & $-0.153 * *$ & $-0.147 *$ & $* *$ \\
\hline 1-6 months & $-0.081 * *$ & $-0.075 * *$ & $-0.095 * *$ & $-0.095 *$ & $* *$ \\
\hline 6 months to less than 1 year & 0.037 & 0.039 & 0.008 & -0.002 & \\
\hline 1 year to less than 3 years & 0.000 & 0.000 & 0.000 & 0.000 & \\
\hline 3 years to less than 5 years & 0.018 & 0.026 & -0.001 & 0.000 & \\
\hline 5 years to less than 10 years & -0.030 & -0.024 & -0.022 & -0.023 & \\
\hline 10 years to less than 15 years & 0.012 & 0.027 & -0.008 & -0.010 & \\
\hline 15 years or more & -0.013 & -0.003 & -0.015 & -0.012 & \\
\hline Permanent employee & 0.000 & 0.000 & 0.000 & 0.000 & \\
\hline Temporary em ployee & $-0.133 * *$ & $-0.127 * *$ & -0.030 & -0.023 & \\
\hline Works up to 19 hours per week & $-0.138 * *$ & $-0.131 * *$ & $-0.135 * *$ & $-0.131 *$ & $* *$ \\
\hline Works 20 -less than 30 hours per week & -0.069 & -0.062 & $-0.115 * *$ & $-0.111 *$ & $* *$ \\
\hline Works 30 -less than 40 hours per week & 0.022 & 0.016 & $-0.037 * *$ & $-0.037 *$ & $* *$ \\
\hline Works 40 -less than 45 hours per week & 0.000 & 0.000 & 0.000 & 0.000 & \\
\hline Works 45 -less than 50 hours per week & $0.061 * *$ & 0.067 * * & 0.015 & 0.021 & \\
\hline Works 50 -less than 60 hours per week & $0.052 * *$ & $0.059 * *$ & 0.031 & 0.043 & \\
\hline Works 60 hours plus per week & 0.058 & 0.065 & 0.097 & 0.094 & \\
\hline Non-union member & 0.000 & 0.000 & 0.000 & 0.000 & \\
\hline Union member & $0.046 * *$ & $0.042 * *$ & $0.069 * *$ & $0.056 *$ & $* *$ \\
\hline Legislators, administrators and managers & 0.000 & 0.000 & 0.000 & 0.000 & \\
\hline Professionals & $0.079 * *$ & 0.059 & $0.087 * *$ & 0.055 & \\
\hline Technicians and associate professionals & 0.035 & 0.025 & 0.007 & -0.018 & \\
\hline Clerks & -0.011 & -0.010 & $-0.114 * *$ & $-0.125 *$ & $* *$ \\
\hline Service and sales workers & -0.012 & -0.024 & -0.048 & -0.049 & \\
\hline Agriculture and fishery workers & $-0.089 * *$ & -0.074 & $-0.143 * *$ & $-0.105 *$ & ** \\
\hline Trades workers & -0.029 & -0.006 & $-0.184 * *$ & $-0.174 *$ & $* *$ \\
\hline Plant and machine operators and assemblers & -0.036 & -0.010 & $-0.148 * *$ & -0.144 & $* *$ \\
\hline Elementary occupations & -0.059 & -0.051 & $-0.141 * *$ & $-0.136 *$ & $* *$ \\
\hline Mainly daytime working pattern & 0.000 & 0.000 & 0.000 & 0.000 & \\
\hline Mainly evening work, $7 \mathrm{pm}-11 \mathrm{pm}$ & -0.050 & -0.005 & 0.009 & 0.027 & \\
\hline Mainly night work, $11 \mathrm{pm}-5 \mathrm{am}$ & -0.034 & -0.009 & 0.109 & $0.140 *$ & ** \\
\hline Changing shift working pattern & $0.127^{* *}$ & $0.141 * *$ & $0.090 * *$ & $0.097 *$ & $* *$ \\
\hline
\end{tabular}

Continued on next page. 
Table 3: Marginal effect estimates from regression models of the probability of receiving education or training (continued)

\begin{tabular}{|c|c|c|c|c|}
\hline & \multicolumn{4}{|c|}{ Regression model } \\
\hline & $\begin{array}{c}\text { Business } \\
\text { sector } \\
\text { controls }\end{array}$ & $\begin{array}{l}\text { Industry } \\
\text { controls }\end{array}$ & $\begin{array}{c}\text { Business } \\
\text { sector } \\
\text { controls }\end{array}$ & $\begin{array}{l}\text { Industry } \\
\text { controls }\end{array}$ \\
\hline & \multicolumn{2}{|c|}{ Males } & \multicolumn{2}{|c|}{ Females } \\
\hline & \multicolumn{2}{|c|}{ Marginal effects } & \multicolumn{2}{|c|}{ Marginal effects } \\
\hline
\end{tabular}

Em ployer characteristics

Private sector

Public sector

Not for profit sector

0-4 em ployees

5-9 em ployees

10-19 employees

20-49 em ployees

50-99 em ployees

100-499 employees

500 plus employees

Agriculture, forestry and fishing

Mining

Manufacturing

Electricity, gas and water supply

Construction

Wholesale trade

Retail trade

Accommodation, cafes and restaurants

Transport and storage

Communication services

Finance and insurance

Property and business services

Government administration and defence

Education

Health and community services

Cultural and recreational services

Personal and other services

\begin{tabular}{|c|c|c|c|}
\hline 0.000 & & 0.000 & \\
\hline $0.063 * *$ & & $0.067 * *$ & \\
\hline $0.120 * *$ & & $0.154 * *$ & \\
\hline$-0.104 * *$ & $-0.114 * *$ & $-0.083 * *$ & $-0.090 * *$ \\
\hline$-0.098 * *$ & $-0.107 * *$ & $-0.057 * *$ & $-0.061 * *$ \\
\hline-0.039 & -0.045 & $-0.064 * *$ & $-0.067 * *$ \\
\hline 0.000 & 0.000 & 0.000 & 0.000 \\
\hline-0.002 & 0.002 & -0.017 & -0.031 \\
\hline 0.032 & 0.025 & -0.007 & -0.014 \\
\hline \multirow[t]{18}{*}{0.026} & -0.005 & 0.033 & 0.001 \\
\hline & -0.064 & & $-0.095 * *$ \\
\hline & 0.044 & & $S$ \\
\hline & $-0.110 * *$ & & -0.052 \\
\hline & 0.140 & & $S$ \\
\hline & -0.056 & & $-0.099 * *$ \\
\hline & -0.060 & & -0.042 \\
\hline & -0.041 & & $-0.076 * *$ \\
\hline & $-0.199 * *$ & & $-0.119 * *$ \\
\hline & $-0.074 * *$ & & 0.085 \\
\hline & -0.018 & & $-0.112 * *$ \\
\hline & 0.015 & & 0.023 \\
\hline & 0.000 & & 0.000 \\
\hline & 0.102 & & $0.132 * *$ \\
\hline & 0.020 & & 0.055 \\
\hline & $0.124 * *$ & & $0.094 * *$ \\
\hline & -0.045 & & 0.017 \\
\hline & $0.131 * *$ & & 0.015 \\
\hline
\end{tabular}

Notes: ** indicates that the marginal effect was statistically significant at the 95 percent confidence level. Each number represents the marginal effect of a movement between the selected and the reference level of the explanatory variable on the probability of having received employer-funded study and training in the past 12 months. This is estimated holding the effects of other explanatory variables constant at their mean levels. The 70-74 year age group has been controlled for in the analysis, but the marginal effect obtained is not shown due to the small sample size. 'Not specified' and 'other' categories for all characteristics have been controlled for in the analysis. Symbol: $S=$ suppressed due to small sample size. 